Article Review

\title{
Penyakit Jantung Koroner dan Antioksidan
}

\author{
Winnie Nirmala Santosa ${ }^{1 *}$, Baharuddin ${ }^{1}$ \\ ${ }^{1}$ Fakultas Kedokteran, Universitas Surabaya, Surabaya-Indonesia \\ * corresponding author: winniesantosa@gmail.com
}

\begin{abstract}
Coronary heart disease (CHD), one of the cardiac diseases, is caused mainly due to the narrowing of the coronary arteries because of atherosclerosis or spasm or a combination of both. Coronary heart disease is one disease that is scary and is still a problem in both developed and developing countries. The oxidative stress originates mainly in mitochondria from reactive oxygen and reactive nitrogen species (ROS/RNS) and can be identified in most of the key steps in the pathophysiology of atherosclerosis and the consequential clinical manifestations of cardiovascular disease. Treatment of coronary heart disease is by pharma cological trea tment and non-pharmacological therapy. One way of non-pharmacological therapy is to eat antioxidants. Several studies have shown that eating antioxidants can reduce LDL oxidation and play a role in inhibiting the process of hardening the arteries.
\end{abstract}

Keywords: antioxidant, coronary heart disease, oxidative stress

Abstrak-Penyakit jantung koroner (PJK) merupakan salah satu penyakit jantung mematikan. Penyebab utama terjadinya penyakit ini a da lah penyempitan arteri koronaria. Penyempitan terjadi karena adanya kondisi ateroskleros is a tau spas me maupun kombinasi dari keduanya. Penyakit jantung koroner masih menjadi masalah utama baik di negara maju maupun negara berkembang. Kejadian ini dipicu oleh stres oksidatif terutama di mitokondria. Adanya oksigen reaktif dan spesies nitrogen reaktif (ROS / RNS) dan dapat diidentifikasi dalam sebagian besar merupakan kunci dalam patofisiologi aterosklerosis dan manifestasi klinis kons ekuensial dari penyakit kardiovaskular. Pengobatan penyakitjantung koroner adalah dengan pengobatan farmakologis dan terapi non-farmakologis. Salah satu cara tera pi non-farmakologis adalah dengan mengkonsumsi antioksidan. Beberapa penelitian telah menunjukkan bahwa penggunaan antioksidan dapat mengurangi oksidasi LDL dan menghambat proses pengerasan pembuluh darah.

Kata kunci: antioksidan, penyakitjantung coroner, stress oksidatif

\section{PENDAHULUAN}

Penyakit jantung koroner (PJK) adalah salah satu penyebab kematian utama di negaranegara maju [1]. WHO mencatat pada tahun 2006, angka kematian penyakit oleh kardiovaskular sejumlah 17,5juta. Angka ini terutama pada penyakit jantung koroner, stroke, dan penyakit jantung rematik. Jumlah kematian ini mengalami peningkatan dari angka 14,4 juta pada tahun 1990 [2]. Kematian ini banyak terjadi dengan serangan jantung tiba-tiba dan tanpa ada gejala apapun sebelumnya [3]. Penyakit jantung koroner termasuk penyakit yang membahayakan karena berada pada sistem sistemik [4].

Pada penyakitjantung koroner, penyakit serebrovaskular dan penyakit arteri perifer, dapat mengakibatkan gangguan fungsi pembuluh darah. Kondisi ini dapat berakibat pada pasokan darah yang tidak cukup ke organ [4]. Ada beberapa faktor risiko yang mengakibatkan penyakit pembuluh darah. Beberapa diantaranya adalah merokok, gaya hidup pola makan yang tidak sehat, aktivitas fisik yang kurang, tekanan darah tinggi, diabetes dan dislipidemia. Namun, terdapat juga faktor lain yang turut berpengaruh seperti faktor genetik dan lingkungan.

\section{Penyakit Jantung Koroner}

Proses PJK dimulai dengan proses arterosklerosis. Aterosklerosis adalah proses kompleks yang melibatkan pengendapan lipoprotein plasma dan proliferasi elemen seluler di dinding arteri. Kondisi kronis ini berkembang melalui serangkaian tahap yang dimulai dengan fattystreaks (kerak lemak) yang sebagian besar terdiri dari pembentukan foam cell (sel busa) dan akhirnya berkembang menjadi timbunan plak yang ditutupi oleh fibrous cap (lesi jaringan ikat) [5]. Plak ini memberikan penghalang untuk aliran darah arteri dan dapat memicu peristiwa klinis, terutama dalam kondisi yang mendukung ruptur plak dan pembentukan trombus. 
Lemak terdiri atas unsur karbon $(\mathrm{C})$, hidrogen $(\mathrm{H})$, dan oksigen $\left(\mathrm{O}_{2}\right)$ dan memiliki sifat yang larut dalam zat-zat pelarut tertentu. Seperti petroleum benzene dan eter [6][8]. Lemak dalam makanan dapat berubah menjadi kolesterol, trigliserida, fosfolipid, dan asam lemak bebas. Pada saat dicerna oleh usus dengan lipase dan kemudian diserap agar masuk ke dalam pembuluh darah. Terdapat juga kolesterol, trigliserida dan fosfolipid yang tidak larut dalam darah sehingga diperlukan ikatan dengan protein untuk membentuk senyawa yang larut, protein ini disebut dengan lipoprotein [6][8].

Terdapat lipoprotein yang berfungsi mengangkut lemak menuju hati disebut dengan kilomikron. Pada organ hati, ikatan lemak tersebut akan terurai dan membentuk kembali unsur-unsur lemak yang ada dan asam lemak yang terbentuk dapat dipakai sebagai sumber energi, kadang juga jika masih terdapat jumlah yang berlebih akan disimpan dalam jaringan lemak. Jika sediaan kolesterol tidak mencukupi, akan diproduksi oleh sel hati. Dari organ hati, low density lipoprotein (LDL) mengangkut kolesterol kemudian dibawa ke sel-sel organ seperti jantung, otak dan lain-lain yang memerlukan untuk dapat berfungsi sebagaimana mestinya [6].

Secara endogen, kolesterol dapat disintesis melalui asetil Ko-A dengan menggunakan Sterol Regulatory Elemen Binding Protein (SREBP-1) dan akan diserap bersama lemak (trigliserida) melalui suatu senyawa protein yang disebut dengan kilomikron. Trigliserida dan kolesterol dilepaskan oleh kilomikron dengan cara meminta bantuan enzim lipoprotein lipase. Enzim ini terdapat dalam pembuluh darah [8].

Setelah dilepaskan, pada hati terjadi kilomikron berubah menjadi kilomikron remnant untuk menjadi VLDL. VLDL disintesis di hati dan berfungsi membawa kolesterol makanan dan Triasilgliserol (TAG) ke pembuluh darah di jaringan otot \& adipose. Jadi, tempat tujuan VLDL pada endotel kapiler jaringan otot dan adipose. VLDL mengalami hidrolisis oleh lipoprotein lipase (LPL) dan degradasi menjadi Intermediate Density Lipoprotein (IDL) Ialu LDL [8].

Triasilgliserol VLDL diuraikan lipoprotein lipase (LPL) menjadi IDL selanjutnya di endositosis hati (triasilgliserol lipase) hati menjadi LDL. Struktur LDL merupakan lipoprotein dengan karakteristik kandungan penyusun utama berupa kolesterol dan memiliki fungsi mengangkut kolesterol ke hati dan esterkolesteril ke jaringan ekstrahepatik. Proses LDL terdapat di hati sekitar 70\% dan di jaringan ekstrahepatik sekitar 30\%. Pengambilan kolesterol LDL diserap melalui endositosis kolesterol diubah menjadi ester kolesterol. LDL berfungsi memelihara membran sel, penyimpanan kolesterol sebagai ester kolesterol, menekan pembentukan HMG-KoA reduktase dan sintesis reseptor LDL. LDL juga dengan mudah mengendap dan teroksidasi dengan senyawa radikal [8]. Inilah yang mengakibatkan terjadinya peyumbatan.

Penyumbatan pembuluh darah tersering dan perlu diwaspadai adanya kadar kolesterol yang tinggi, terlebih lagi terdapat kadar kolesterol LDLyang tinggi, yang dikenal sebagai “lemak jahat" $[9,10]$.

Inflamasi dalam banyak penelitian terbukti berperan penting dalam setiap tahapan proses aterosklerosis. Proses aterosklerosis berawal dari proses inisiasi sampai tahap lanjut hingga terjadinya ruptur plak. Proses ini yang dapat menimbulkan komplikasi penyakit kardiovaskular. Aterosklerosis dikatakan sebagai suatu penyakit inflamasi disebabkan hasil proses inflamasi dari sel yang berperan berupa makrofag yang berasal dari monosit dan limfosit [9]. Fase pembentukan aterosklerosis terdiri atas fase awal yaitu terjadi akumulasi dan modifikasi lipid (oksidasi, agregasi, dan proteolisis) dalam dinding arteri yang dapat mengakibatkan aktivasi inflamasi endotel dan pada fase selanjutnya terjadi pemilihan elemenelemen inflamasi seperti monosit yang awalnya menempel pada endotel ke dalam tunika intima.

Endotel yang menempel ini diperantarai oleh beberapa molekul adhesi, yaitu Inter Cellular Adhesion Molecule-1 (ICAM-1), Vascular Cell Adhesion Molecule-1 (VCAM-1), dan selectin. Beberapa faktor yang mengatur molekul adhesi, yaitu produk bakteri lipopolisakarida, prostaglandin, dan sitokin. Monosit setelah berikatan dengan endotel akan berpenetrasi ke lapisan yang lebih dalam dibawah lapisan intima. Dinding arteri yang dimasuki oleh monosit-

(c) (i) (2) http://joumal.ubaya.ac.id/index.php/kesdok | e-ISSN: 2715-6419


monosit mengakibatkan monosit berubah menjadi makrofag dan menghancurkan LDL yang telah dioksidasi melalui reseptor scavenger [9].

Pembentukan sel busa (foam cell) dihasilkan dari fagositosis yang kemudian berlanjut menjadifatty streaks. Aktivasi ini menghasilkan sitokin dan faktor-faktor pertumbuhan yang akan merangsang proliferasi dan migrasi sel-sel otot polos. Migrasi ini terjadi dari tunika media ke tunika intima. Kondisi ini mengakibatkan pula penumpukan molekul matriks ekstraselular, seperti elastin dan kolagen, yang mengakibatkan plak membesar dan terbentuk fibrous cap. Pada tahap ini proses aterosklerosis sudah sampai pada kondisi membahayakan karena telah ada plak aterosklerotik. Pembentukan plak aterosklerotik akan menyebabkan lumen arteri menyempit. Pada akhirnya terjadi pengurangan aliran darah $[9,11]$.

Setelah terjadi ruptur plak aterosklerosis, platelet yang aktif dan jalur koagulasi, kemudian akan terjadi trombosis. Proses trombogenik terjadi ketika plak tersebut pecah, robek, atau terjadi perdarahan subendotel. Hal ini dapat menyumbat sebagian atau keseluruhan suatu arteri koroner. Keadaan ini yang dapat menimbulkan gejala klinik seperti angina atau infark miokard. Kejadian aterosklerosis ini dapat stabil, akan tetapi dapat juga progresif. Kondisi progresif yang parah dapat menyebabkan kematian. Konsekuensi yang progresif ini dikenal juga dengan sindroma koroner akut $[9,10]$.

\section{Penyakit jantung koroner dan stres oksidatif}

Stres oksidatif adalah kondisi radikal bebas atau prooksidan yang lebih tinggi dibandingkan antioksidan. Artinya terjadi ketidakseimbangan jumlah oksidan di dalam sel. Hal ini dipicu oleh kurangnya antioksidan serta kelebihan produksi radikal bebas [11]. Radikal bebas ini dapat berasal dari metabolisme dan lingkungan.

Secara umum disfungsi jantung, penyakit kardiovaskular, apoptosis dan nekrosis jantung dapat diakibatkan oleh radikal bebas atau reactive oxygen species (ROS) dan hiperlipidemia. Dalam sistem kardiovaskular, ROS dapat menyebabkan hipertrofi pada sel otot polos dan dinding arteri, kerusakan sel kardiomiosit, apoptosis dan kerusakan miokard. Hal ini dapat terjadi dan dikaitkan dengan peningkatan denyut jantung serta kenaikan tekanan darah sistolik [13].

Salah satu ROS terpenting dalam pembuluh darah dan jantung adalah superoksida $\left(\mathrm{O}_{2}\right)$, hidrogen peroksida $\left(\mathrm{H}_{2} \mathrm{O}_{2}\right)$, dan oksida nitrat (NO) [12]. Reaksi ini dimediasi oleh beberapa sistem enzim termasuk NADPH oksidase dan xanthine oxidase (XO). Meskipun $\mathrm{O}_{2}{ }^{-}$ bisa dengan sendirinya memberikan efek pada fungsi vaskular, itu juga penting dalam menghasilkan spesies reaktif lainnya. Reaksi $\mathrm{O}_{2}{ }^{-}$dengan $\mathrm{NO}$ menghasilkan peroxynitrite dan berpotensi yang merusak ROS. Dismutase $\mathrm{O}_{2}$ oleh superoksida dismutase (SOD) menghasilkan ROS yang lebih stabil, hidrogen peroksida $\left(\mathrm{H}_{2} \mathrm{O}_{2}\right)$ yang kemudian diubah secara enzimatik menjadi $\mathrm{H}_{2} \mathrm{O}$ oleh katalase dan glutathione peroxidase $(\mathrm{GPx}) . \mathrm{H}_{2} \mathrm{O}_{2}$ bisa juga bereaksi dengan logam transisi yang dikurangi untuk dikonversi menjadi radikal hidroksil yang sangat reaktif $(\cdot \mathrm{OH})$, atau bisa juga dimetabolisme oleh myeloperoxidase (MPO) untuk membentuk asam hipoklorus ( $\mathrm{HOCl}$ ). Hampir semua jenis sel vaskular menghasilkan $\mathrm{O}_{2}^{-}$dan $\mathrm{H}_{2} \mathrm{O}_{2}$ [13].

Beberapa sistem enzimatik menghasilkan $\mathrm{O}^{-}$dan turunannya di pembuluh darah, termasuk NADPH oksidase, XO, nitrat oksida sintase (NOS), dan myeloperoxidase (MPO). NADPH oksidase sangat penting dalam fungsi vaskular karena respons terhadap berbagai macam agonis, seperti angiotensin (Ang) II. Aktivasi enzim terjadi dalam jangka pendek dengan stimulasi intraseluler spesifik signals dan dalam jangka panjang dengan upregulation dari subunit enzim. Bahkan konsentrasi Ang II rendah (0,1 nmol/L) meningkatkan NADPH oksidase, penurunan ROS menunjukkan bahwa sistem enzim ini penting secara fisiologis. NADPH oksidase juga sebagai penentu penting dari keadaan redoks pembuluh darah dan miokardium [14].

Xanthine Oxidase (XO) memetabolisme hipoksantin, xanthine, dan NADPH untuk membentuk $\mathrm{O}_{2}{ }^{-}$dan $\mathrm{H}_{2} \mathrm{O}_{2}$. ROS yang dihasilkan $\mathrm{XO}$ telah terlibat dalam berbagai entitas patologi klinik, termasuk cedera iskemia/ reperfusi, hiperkolesterolemia dan disfungsi endotel 
pada gagal jantung kronis. MPO melimpah di fagosit dan mengkatalisasi $\mathrm{H}_{2} \mathrm{O}_{2}$ menghasilkan $\mathrm{HOCl}$ dan spesies pengoksidasi lainnya, juga menggunakan NO untuk menghasilkan spesies nitrogen reaktif, dengan demikian mengurangi bioaktivitas NO dan meningkatkan stres oksidatif [15].

\section{Efek antioksidan dan penyakit jantung coroner}

Untuk mencegah kerusakan sel akibat radikal bebas, tubuh manusia memiliki mekanisme pertahanan intrinsik yang dikenal sebagai sistem antioksidan. Pembentukan oksidan dan peroksidasi lipid dapat dicegah dengan antioksidan dengan memberikan perlindungan kepada LDL dari proses oksidasi. Antioksidan ini memiliki reaksi terminasi yaitu dengan cara menangkap radikal hidroksil $(* \mathrm{OH})$ pada tahap reaksi peroksidasi lemak, protein atau molekul lainnya pada membran sel normal. Antioksidan juga dapat melindungi jaringan dari kerusakan akibat ROS [17].

Dalam sel tubuh terdapat antioksidan yang diproduksi secara alami biasanya terdapat dalam bentuk antioksidan yang enzimatik maupun nonezimatik dan memiliki fungsi sebagai pertahanan bagi organel-organel sel dari pengaruh kerusakan akibat reaksi radikal bebas [16]. Antioksidan enzimatik disebut juga antioksidan pencegah, terdiri atas superoksid dismutase (SOD), katalase, dan glutathione peroxidase [17].

Enzim antioksidan mengatalisis pemecahan spesies radikal biasanya di lingkungan intraseluler. Antioksidan preventif mengikat ion logam transisi seperti besi dan tembaga, mencegah interaksi dengan hidrogen peroksida dan superoksida untuk menghasilkan radikal hidroksil yang sangat reaktif. Antioksidan adalah donor elektron yang kuat dan bereaksi istimewa dengan radikal bebas sebelum molekul target yang lebih penting rusak. Dalam melakukan itu antioksidan dikurangi (teroksidasi) dan harus diregenerasi atau diganti. Antioksidan radikal relatif tidak reaktif dan tidak mampu menyerang lebih jauh molekul [17].

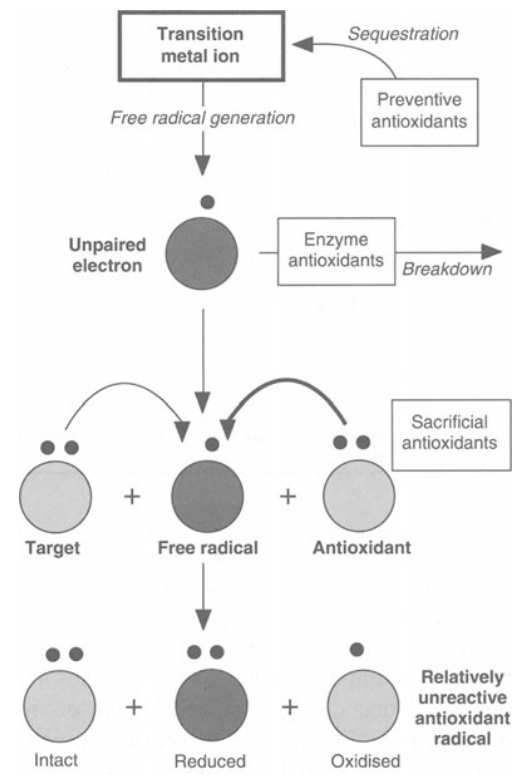

Gambar 1. Interaksi radikal bebas dan antioksidan [18].

Di sisi lain, antioksidan nonenzimatik disebut juga antioksidan pemecah rantai yang berasal dari $\alpha$-tokoferol (vitamin E), $\beta$-carotene (vitamin A), askorbat (vitamin C), glutathione, estrogen, L- tyrosine, L- cysteine, NADPH, ferritin dan albumin [18]. Berbagai fungsi vitamin C dapat mendukung hipotesis bahwa vitamin $C$ dapat mengurangi risiko kardiovaskular. Vitamin C (L-asam askorbat) merupakan antioksidan yang ampuh dikenal untuk melindungi jaringan dari cedera oksidatif [19]. Vitamin C juga dapat meningkatkan fungsi jantung, meningkatkan perlindungan jantung selama perbaikan miokardial, menghambat apoptosis sel endotel pada gagal jantung kongestif, menurunkan tekanan darah diastolik, dan meningkatkan vasorelaksasi 
endothelium. Vitamin C juga telah terbukti mengurangi adhesi monosit ke endotelium, meningkatkan produksi oksida nitrat dari endotelium, meningkatkan vasodilatasi dan menurunkan tekanan darah. Selanjutnya, vitamin C dapat mencegah apoptosis sel otot polos pembuluh darah, yang membantu menjaga plak lebih stabil jika aterosklerosis telah berkembang dan melindungi sel otot polos pembuluh darah manusia terhadap adaptasi LDL terinduksi teroksidasi peningkatan sintesis antioksidan intraseluler glutathione [20].

\section{SIMPULAN}

Strategi dalam menangani kondisi penyakit jantung koroner melalui pemberian antioksidan sampai saat ini masih kurang mendapat perhatian. Review ini mencoba memberikan penjelasan ilmiah terkait hubungan antara penyakit jantung koroner dan konsumsi antioksidan. Antioksidan ini berpotensi sebagai terapi pendukung dalam mengatasi kondisi penyakit jantung koroner sekaligus dapat mengurangi munculnya komplikasi. Pada akhirnya dapat menekan tingginya angka morbiditas dan mortalitas akibat penyakit jantung koroner.

\section{PUSTAKA ACUAN}

1. Murray C, Lopez AD. 1997. Mortality by cause for eight regions of the world: Global Burden of Disease Study. Lancet 349:1269-76.

2. World Health Organization; 2006 [diakses tanggal2 April 2016]. Tersedia dari: www.who.int/cardiovascular_diseases/cvd 14 deathHD.pdf

3. Davidson, C. 2002. Penyakit jantung koroner. Jakarta: PT Dian Rakyat.

4. World Health Organization. Cardiovascular diseases (CVDs). 2013. Available from: URL:http: //www.who.int/mediacentre/ factsheets/fs317/en/index.html

5. Ross R. 1993. The pathogenesis of atherosclerosis: a perspective for the 1990s. Nature. 362:801-809.

6. Okada, T., Hara, M., E. Saitou, F. Iwata, dan K. Harada. Waist-to-height ratio is the best predictor of cardiovaskular disease risk factor on Japanese children. J. Atheroscler. Thromb. 2007. 9 (3):127-132.

7. Soeharto I. 2002. Kolesterol dan lemak jahat kolesterol, lemak baik dan proses terjadinya serangan jantung dan stroke. Cetakan kedua. Jakarta: PT Gramedia Pustaka Utama.

8. Maulana, M. 2008. Penyakit Jantung: Pengertian, Penanganan dan Pengobatan. Yogyakarta: Penerbit Kata Hati.

9. Anwar TB. 2004. Faktor risiko penyakit jantung koroner. Sumatera Utara: E-USU Repository.

10. Scalzo J, Politi A, Pellegrini N, Mezzetti B, Battino M. 2005. Plant genotype affects total antioxidant capacity and phenolic contents in fruit. Nutrition. 21(2):207-13.

11. Baigent C, Keech A, Kearney P, et al. Atherosclerosis[internet]. USA: American Heart Association; 2013 [diakses tanggal 2 April 2016]. Tersedia dari: http://www.heart.org/HEARTORG/Conditions/Cholesterol/WhyCholesterolMatters/Ath erosclerosis_UCM_305564_Article.jsp

12. Benhar M, Engelberg D, Levitski A. 2002. Reactive oxygen species (ROS), stress-activated kinases, and stress signaling in cancer. EMBO reports. 3(5):420-5.

13. Cooper GM, Hausman RE. The cell a molecular approach. Washington: ASM Press; 2003.

14. Taniyama Y and Griendling KK. Reactive Oxygen Species in the Vasculature: Molecular and Cellular Mechanisms. Hypertension. 2003; 42:1075-1081.

15. Griendling KK, Sorescu D, Ushio-Fukai M. NADPH oxidase: role in cardiovascular biology and disease. Circ Res 2000;86:494-501.

16. Landmesser U, Merten R, Spiekermann S, Buttner K, Drexler H, Hornig B. 2000. Vascular extracellular superoxide dismutase activity in patients with coronary artery disease: relation to endothelium-dependent vasodilation. Circulation 101:2264-2270. 
17. Evans JL, Goldfine ID, Maddux BA dan Grdsky GM, 2003. Are Oxidative Stress Activated Signaling Pathways Mediators Of Insulin Resistance And Cell Dysfunction?, Diabetes; vol. 52, no. 1:1-8.

18. Marciniak A, Brzeszczynska J, Gwozdzinski K, Jegier A, 2009. Antioxidant Capacity and Physical Exercise. Biology of Sport, Vol. 26 No3, 197-213.

19. Lee IM, 1999. Antioxidant vitamins in the prevention of cancer. Proc Assoc Am Physicians; 111: 10-5.

20. Frei $B, 1999$. On the role of vitamin $C$ and other antioxidants in atherogenesis and vascular dysfunction. Proc. Soc. Exp. Biol. Med. 222, 196-204.

21. Shapiro SS, Saliou C, 2001. Role of vitamins in skincare. Nutrition [homepage on the Internet cited: 2012 Jan 13]. Available from: http://dexa-medica.com. 